\title{
The Interaction between the Bulking Water and Pipe Surface and Their Correlations in Water Distribution System
}

\author{
Ruilian $\mathrm{Li}^{1}$, Ming-qing Feng ${ }^{2}$, Xiao-hui Bai ${ }^{2 *}$ \\ 1. College of Information Engineering, Taiyuan University of Technology, Shanxi, 030024, \\ CHINA \\ 2. Lab of Water Science and Technology, College of Life Sciences and Biotechnology, \\ Shanghai Jiao Tong University, Shanghai, 200240, CHINA \\ E-mail: xhbai@sjtu.edu.cn
}

\begin{abstract}
The pipelines corrosion can result discolor and particle increase in tap water and the complaints from the consumers. It also has the economic and hydraulic impacts for the replacement of broken pipes and fouling of corroded pipes. This paper aimed to investigate the effect of processed drinking water on metal pipe corrosion in water distribution system and the relations between the bulking water quality and pipe corrosion. It was found that there is a close relation between iron corrosion and water quality parameters in water distribution pipelines. It was shown that lower $\mathrm{pH}$ and alkalinity can increase the corrosion rate, while higher chlorides and sulfate may cause pitting corrosion. DOC in pipe water would be beneficial for microbial induced corrosion.
\end{abstract}

Key Words: Water distribution system; drinking water quality; iron corrosion; chemical stability; microbial induced corrosion

\section{Introduction}

Because of the complicated biochemical reaction between the bulking pipe water and the pipe surface, the treated water meeting the standards for drinking water quality can't always guarantee the water chemical stability and results from the occurrence of discolor and sand particles in tap water and the complaints of customers on water quality. The pipelines corrosion have been investigated for years since the corrosion has economic, hydraulic and aesthetic impacts, including water leaks, corrosion scales formation, and water quality deterioration[1]. An increase in turbidity, Fe concentration, quick decay of disinfectant residual and sometimes even appearance of unpleasant smell or color of water may result from the corroded system[2-4]. Iron corrosion is also the primary factor controlling biofilm growth.

The mechanism of iron corrosion processes can be a series of electrochemical or/ and microbial reaction occurring at the metal surface in contact with bulking water[5-7]. The metal is converted into ferrous solids (e.g. $\mathrm{Fe}(\mathrm{OH})_{2}$ ) which may then be converted to ferric solids (e.g. $\left.\mathrm{Fe}(\mathrm{OH})_{3}\right)$ after reaction with oxygen. This complex process is believed to be influenced by many parameters of the bulking water: oxygen, $\mathrm{pH}$, alkalinity, chloride and sulfate, water temperature, disinfectant residual, NOM, etc.[8-11]. Biodegradable dissolved organic carbon (BDOC) and assimilated organic carbon (AOC) are stated to be responsible for microbiological corrosion[12,7,10].

The chemical stability indexes were proposed to demonstrate the corrosiveness and aggressiveness of the water to cement and iron pipelines[13-15]. Langelier took the effect of $\mathrm{pH}$, alkalinity, hardness and dissolved solids into account to study the equilibrium of calcium carbonate in water. By calculating the $\mathrm{pHs}$ of water according to standard methods for examination of water and wastewater, Langelier Saturation Index can indicate whether calcium is tend to precipitate or dissolve. LSI has its own shortage and sometimes gives wrong judgments. Ryznar modified LSI and proposed new index: RSI. Nowadays, LSI and RSI are combined to reveal the chemical stability of drinking water[16]. There also exist many other indexes to evaluate the water corrosiveness to water distribution pipelines: Larson Ratio (LR) was aimed to demonstrate the water corrosiveness to iron pipes, and AI was used to illustrate the aggressiveness to iron pipe with cement mortar lining. However, there are some controversy to these indexes and they are hard to be applied worldwide[16]. It was suggested that the limitation should be regularized according to the local conditions.

In this study, we aimed to find the changing rule of water quality while finished water was distributed through the pipelines and the correlations between the bulking water quality and pipe corrosion by establishing a model with the help of statistics software. The correlations between the quality parameters and iron content can give an insight to formulate the chemical stability indexes adaptable to local distribution systems. 


\section{Experimental method}

\subsection{Water samples collection}

Two large distribution system supplied by two water treatment plants and producing water from the same surface source water of Huangpu River were investigated for the bulking water quality. The first plant uses the conventional process of coagulation and sedimentation with aluminum sulfate, sand filtration and disinfection with sodium hypochlorite. The second plant treats the same source water by coagulation and sedimentation with PACS, sand filtration, ozone oxidation and biological activated carbon process and disinfection with sodium hypochlorite. Fourteen different sampling points were selected along the two main pipelines of the two distribution systems, 8 from the first water treatment plant supply system and 6 from the second water supply system. Most of the pipes in the distribution system are made of nodular cast iron with cement coating, while the rest of the pipes are aged cast iron pipes and plastic pipes. These sampling points are shown in Fig. 1. These water samples were collected and tested seven times during a seven-month sampling period from July 2009 to January 2010.
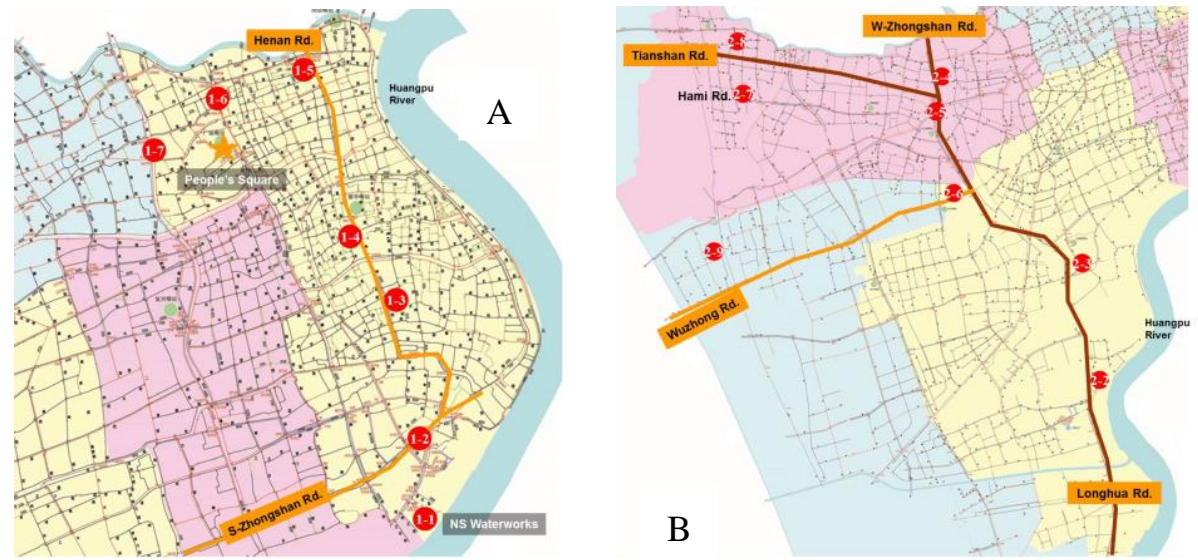

Figure 1 Sampling points in water distribution system (A: area by first plant; B: area by second plant)

\subsection{Water quality analyses}

Water sample pretreatment and analyses were undertaken in a certified laboratory using Chinese standard methods according to Standards for Drinking Water Quality (GB 5750-2006). The parameters of pH, turbidity and total chlorine residual were tested just after the sample collection.

The Langelier Saturation Index (LSI), the Ryznar Stability Index (RSI) and the Larson Ratio (LR) were used to evaluate the chemical stability of the bulking water in the distribution system[13-15].

\section{Results and discussion}

\subsection{Water quality in the water distribution system}

Effluent from two different water treatment plants and bulking water in the corresponding distribution network were sampled and tested. The results were shown in table 1 and table 2. The finished water from the first treatment plant has higher $\mathrm{pH}$, alkalinity, $\mathrm{DOC}$ and lower turbidity, sulfate and iron content than from the second treatment plant. Further investigations revealed that water coagulated with aluminum sulfate had higher sulfate content, lower $\mathrm{pH}$ and alkalinity than water treated with PACS.

Results in table 1-2 reveals the same changes in water quality from finished water to pipe water in both distribution networks. In the bulking water, $\mathrm{pH}$, alkalinity, total chlorine residual and sulfate were lower than them in finished water. The hardness was similar in these water samples, while there was an increase in turbidity, chlorides, DOC and iron ions during the water distributing. Langelier Saturation Index (LSI), Ryznar Stability Index (RSI) and Larson Ratio (LR) of these water samples show great aggressiveness and corrosiveness to the cast pipe with cement coating ( RSI $>8.00, \mathrm{LSI}<0.00$ and $\mathrm{LR}>0.50$ ). It can be found that the effluent water quality from waterworks determined the water chemical stability in the water distribution system.

In table 1 and table 2, Pipe water carries higher suspended solid particles and iron than finished water. Some samples have an iron content up to $0.3 \mathrm{mg} / \mathrm{L}$, which is above the limitation quoted from Standards for Drinking Water Quality (GB 5749-2006). The corroded iron pipes are the main source of the extra iron content in pipe water. Since all the bulking water samples contain much higher iron than finished water, there exists a common corrosion phenomenon in the distribution pipeline. The corrosion scales attached to the inner wall was released 
while water flush the pipe continuously, causing an increase of iron content and turbidity in pipe water.

Table 1. Water quality in the distribution system supplied by the first treatment plant (average values)

\begin{tabular}{|c|c|c|c|c|c|c|c|c|c|}
\hline Parameter & Effluent & $\begin{array}{c}\text { Location } \\
1\end{array}$ & $\begin{array}{c}\text { Location } \\
2 \\
\end{array}$ & $\begin{array}{c}\text { Location } \\
3 \\
\end{array}$ & $\begin{array}{c}\text { Location } \\
4\end{array}$ & $\begin{array}{c}\text { Location } \\
5\end{array}$ & $\begin{array}{c}\text { Location } \\
6\end{array}$ & $\begin{array}{c}\text { Location } \\
7\end{array}$ & $\begin{array}{c}\text { Location } \\
8 \\
\end{array}$ \\
\hline $\mathrm{pH}$ & 7.19 & 7.18 & 7.13 & 7.11 & 7.10 & 7.16 & 7.09 & 7.10 & 7.07 \\
\hline Turbidity[NTU] & 0.09 & 0.22 & 0.25 & 0.27 & 0.24 & 0.35 & 0.43 & 0.35 & 0.26 \\
\hline $\begin{array}{l}\text { Alkalinity } \\
{\left[\mathrm{mg} \cdot \mathrm{L}^{-1}\right]}\end{array}$ & 85.95 & 84.54 & 84.24 & 85.04 & 85.27 & 85.95 & 85.52 & 83.54 & 84.36 \\
\hline $\begin{array}{l}\text { Hardness } \\
{\left[\mathrm{mg} \cdot \mathrm{L}^{-1}\right]}\end{array}$ & 209.56 & 205.25 & 206.16 & 208.42 & 209.74 & 211.46 & 211.38 & 208.72 & 210.60 \\
\hline \multicolumn{10}{|l|}{ Chlorine } \\
\hline $\begin{array}{l}\text { Residual } \\
{\left[\mathrm{mg} \cdot \mathrm{L}^{-1}\right]}\end{array}$ & 2.06 & 1.49 & 1.29 & 0.79 & 1.04 & 0.72 & 0.21 & 0.33 & 0.60 \\
\hline $\mathrm{Cl}^{-}\left[\mathrm{mg} \cdot \mathrm{L}^{-1}\right]$ & 76.52 & 78.25 & 79.65 & 80.65 & 79.58 & 80.12 & 79.74 & 79.61 & 80.70 \\
\hline $\mathrm{SO}_{4}{ }^{2-}\left[\mathrm{mg} \cdot \mathrm{L}^{-1}\right]$ & 90.90 & 89.96 & 87.55 & 89.18 & 88.41 & 86.61 & 90.64 & 89.10 & 87.82 \\
\hline $\mathrm{DOC}\left[\mathrm{mg} \cdot \mathrm{L}^{-1}\right]$ & 5.57 & 5.83 & 5.96 & 5.67 & 5.74 & 5.76 & 5.85 & 5.75 & 5.71 \\
\hline $\mathrm{Fe}\left[\mathrm{mg} \cdot \mathrm{L}^{-1}\right]$ & 0.05 & 0.07 & 0.15 & 0.14 & 0.15 & 0.15 & 0.17 & 0.15 & 0.11 \\
\hline RSI & 8.09 & 8.19 & 8.22 & 8.21 & 8.20 & 8.15 & 8.15 & 8.19 & 8.22 \\
\hline LSI & -0.45 & -0.51 & -0.55 & -0.55 & -0.55 & -0.50 & -0.53 & -0.55 & -0.58 \\
\hline LR & 1.87 & 1.87 & 1.91 & 1.96 & 1.94 & 1.93 & 1.95 & 1.98 & 1.95 \\
\hline
\end{tabular}

Table 2. Water quality in the distribution system supplied by the second treatment plant (average values)

\begin{tabular}{|c|c|c|c|c|c|c|c|}
\hline Parameter & Effluent & $\begin{array}{c}\text { Location } \\
9 \\
\end{array}$ & $\begin{array}{c}\text { Location } \\
10 \\
\end{array}$ & $\begin{array}{c}\text { Location } \\
11 \\
\end{array}$ & $\begin{array}{c}\text { Location } \\
12 \\
\end{array}$ & $\begin{array}{c}\text { Location } \\
13 \\
\end{array}$ & $\begin{array}{c}\text { Location } \\
14 \\
\end{array}$ \\
\hline $\mathrm{pH}$ & 6.98 & 6.98 & 6.99 & 6.95 & 6.96 & 6.95 & 6.95 \\
\hline Turbidity[NTU] & 0.32 & 0.31 & 0.39 & 0.63 & 0.39 & 0.50 & 0.61 \\
\hline $\begin{array}{l}\text { Alkalinity } \\
{\left[\mathrm{mg} \cdot \mathrm{L}^{-1}\right]}\end{array}$ & 76.21 & 74.33 & 75.45 & 75.93 & 77.07 & 74.68 & 76.92 \\
\hline $\begin{array}{l}\text { Hardness } \\
{\left[\mathrm{mg} \cdot \mathrm{L}^{-1}\right]}\end{array}$ & 209.94 & 207.06 & 206.58 & 209.09 & 208.59 & 210.60 & 207.44 \\
\hline $\begin{array}{l}\text { Zhlorine Residual } \\
{\left[\mathrm{mg} \cdot \mathrm{L}^{-1}\right]}\end{array}$ & 1.61 & 1.60 & 1.47 & 0.73 & 1.15 & 0.53 & 0.30 \\
\hline $\mathrm{Cl}^{-}\left[\mathrm{mg} \cdot \mathrm{L}^{-1}\right]$ & 77.07 & 78.16 & 78.56 & 79.30 & 79.30 & 80.13 & 77.74 \\
\hline $\mathrm{SO}_{4}{ }^{2-}\left[\mathrm{mg} \cdot \mathrm{L}^{-1}\right]$ & 105.84 & 101.54 & 99.74 & 102.40 & 104.63 & 106.43 & 105.65 \\
\hline $\mathrm{DOC}\left[\mathrm{mg} \cdot \mathrm{L}^{-1}\right]$ & 4.97 & 5.53 & 5.26 & 5.25 & 5.24 & 5.74 & 5.32 \\
\hline $\mathrm{Fe}\left[\mathrm{mg} \cdot \mathrm{L}^{-1}\right]$ & 0.11 & 0.22 & 0.23 & 0.27 & 0.23 & 0.32 & 0.29 \\
\hline RSI & 8.21 & 8.35 & 8.50 & 8.46 & 8.33 & 8.45 & 8.37 \\
\hline LSI & -0.62 & -0.69 & -0.76 & -0.76 & -0.69 & -0.75 & -0.71 \\
\hline LR & 2.18 & 2.22 & 2.24 & 2.30 & 2.21 & 2.34 & 2.23 \\
\hline
\end{tabular}

The $\mathrm{pH}$ in bulking water is much lower than that of finished water, showing a descending trend along the distribution network. Taking the distribution network supplied by the first treatment plant as example, there was an obvious descending trend in the $\mathrm{pH}$ of water from water plant to location 4 . This can also be found in pipe water from location 5 to 8 . The $\mathrm{pH}$ decrease in the pipe water can be explained by chloramines decay and carbon dioxide dissolving. Other studies demonstrated the relationship between $\mathrm{pH}$ and iron corrosion. Génin et al.[17] and Refait et al.[18] proposed the scheme of "green rust" formation, showing that the water $\mathrm{pH}$ decreased during the rust formation. Tuovinen et al.[19]reported a significantly lower $\mathrm{pH}$ in tubercles interior and the oxidation of iron is recognized as one of the main mechanisms of water acidification.

The same descending trend can also be found in the alkalinity, but the trend is less obvious than that of water $\mathrm{pH}$. The positive correlation between $\mathrm{pH}$ and alkalinity shows that the decrease in water $\mathrm{pH}$ makes carbonate and bicarbonate more unstable. It should be mentioned that there are three pumping stations with several cement reservoirs sited between Location 4-5, 11-12 and 13-14. Water stagnancy in the cement reservoirs may cause alkaline component dissolve to water. This explains well why the $\mathrm{pH}$ and alkalinity of pipe water increase uncommonly at these sampling points.

Hardness analysis reveals much divergent results. Some of the pipe waters contain more calcium and magnesium but in some other samples, fewer concentrations was detected than those in finished water. The Langelier Saturation Index (LSI) and the Ryznar Stability Index (RSI) show great aggressiveness and corrosiveness to cement coating, which might cause an increase of hardness in pipe water. However, the correlation between hardness and LSI or RSI is not notable. We assume that pipe water quality is not the only reason of the cement corrosion, other factors should be taken into account to explain the phenomenon, such as 
water stagnancy and pipe material.

Pipe water contains higher amounts of chlorides when compared to their concentrations in finished water. This might be the result of the chloramines decay and there is a positive correlation between chlorides and chlorine residual.

The concentration of sulfate in pipe water samples varies with a very narrow range. Majority of sulfate values in pipe water are lower than those of finished water. Immobilization to the inner wall is the main reason of the decrease of sulfates. Taking the strong affinity of corrosion scale to sulfates into account, we could infer that the anions are preferentially adsorbed to build the green rusts in sulfate form.

Pipe water also carries a higher load of dissolved organic carbon than finished water. Morton et al.[20]suggested that during stagnant conditions, or in anodic areas, corrosion might be a significant source of dissolved organic carbon produced by autotrophic iron-oxidizing and hydrogen bacteria. Also Beech and Gaylarde[21]stated that some kinds of organic acids (mainly acetic, formic and lactic acids) are common metabolic by-products released to distributed water by aerobic organic acid-producing bacteria (APB). Nawrocki et al.[22]found that the DOC content is much higher in static water than in flowing water. Since LDH (layered double hydroxides) are commonly found in corrosion scales and are labile, the destruction of the scales is responsible for the mix with steady water and flowing water, causing the increase of DOC concentration[18,23,24].

\subsection{Relations between water quality and corrosion}

As the iron corrosion can cause an increase of Fe concentration and high iron content results in unpleasant color of the drinking water, Iron content is used to demonstrate the corrosion performance of the distribution pipelines. The Pearson correlation between iron content and other water quality parameters were calculated by using SPSS 14.0. The results from Table 3 reveals that there exists quite strong correlation between iron content and pipe water quality parameters, except the hardness. Iron content has a strong positive correlation with turbidity, revealing that the suspended iron particle flushed from the corrosion scales is one of the components of suspended solid particles.

Table 3. The correlation between water quality and iron content

\begin{tabular}{ll}
\hline Parameter & $\mathrm{Fe}$ \\
\hline $\mathrm{pH}$ & -0.823 \\
Turbidity & 0.838 \\
Alkalinity & -0.744 \\
Hardness & -0.007 \\
$\mathrm{Cl}^{-}$ & 0.884 \\
$\mathrm{SO}_{4}{ }^{2-}$ & 0.702 \\
$\mathrm{DOC}$ & 0.719 \\
$\mathrm{RSI}$ & 0.856 \\
LR & 0.854 \\
\hline
\end{tabular}

The negative correlation between $\mathrm{pH}$ and iron content demonstrates that lower $\mathrm{pH}$ in pipe water can benefit the iron corrosion process. Compared the changes of iron content in finished water and pipe water from two distribution system networks supplied by two different treatment plants, water with lower $\mathrm{pH}$ in the second distributing network has a more obvious increase in iron content. Iron content of pipe water in the first network rise from 0.02 to $0.12 \mathrm{mg} / \mathrm{L}$, while the increase of that in the second network is up to $0.11-0.21 \mathrm{mg} / \mathrm{L}$. Boffardi [25]stated that the decrease in $\mathrm{pH}$ may cause an increase of iron corrosion rate. Lasheena et al.[26]assess the effect of stagnation time, pipe age and water quality parameters such as $\mathrm{pH}$, alkalinity and chloride on iron release from galvanized iron pipes, by using fill and dump method. They found that more iron was released from the galvanized iron pipes transporting weakly acid water than those with alkaline water. Other studies also showed lower $\mathrm{pH}$ may result in higher iron corrosiveness of water.

There also exists a negative correlation between iron content and alkalinity, which implies that carbonate and bicarbonate in water may lower the corrosion rate. Langlier[13]proposed that if the water with a slight high alkalinity, a thin film of calcium carbonate would precipitate on the surface and protect the metal from further corrosion. Later investigations showed that siderite also plays an important role as an intermediate in the formation of protective layers. Sontheimer, H. et al.[27]stated that free carbon dioxide acts as a proton donor at surface hydroxide sites. This increases the solubility of iron ions and stimulates iron corrosion.

Chlorides are considered as anions that stimulate corrosion and thus their positive correlations with iron content can be found in this study. Baylis[28]and Tuovinen et al.[19]stated that chlorides accumulate on tubercular deposits as well as metal surfaces in localized pitting corrosion. The mechanism of chlorides destroying the passive layer has long been a research focus. Strehblow[29]proposed several possible mechanisms. Adsorption mechanism stated that the attachment of the aggressive anions may stimulate the breakdown of the 
passive layer. Anions' transferring from liquid to metal surface is regards as the rate determining step according to the permeable mechanism, which was detected by using modern surface physics methods, such as AES and XPS[30]. Since the chlorine ion has the smallest diameter and highest electronegativity, the adsorption and permeation is most likely to occur during the pitting corrosion. Adsorption mechanism and permeable mechanism can also explain the positive correlation between sulfate and iron content. The anions are tend to be adsorbed to build the corrosion scale in sulfate form.

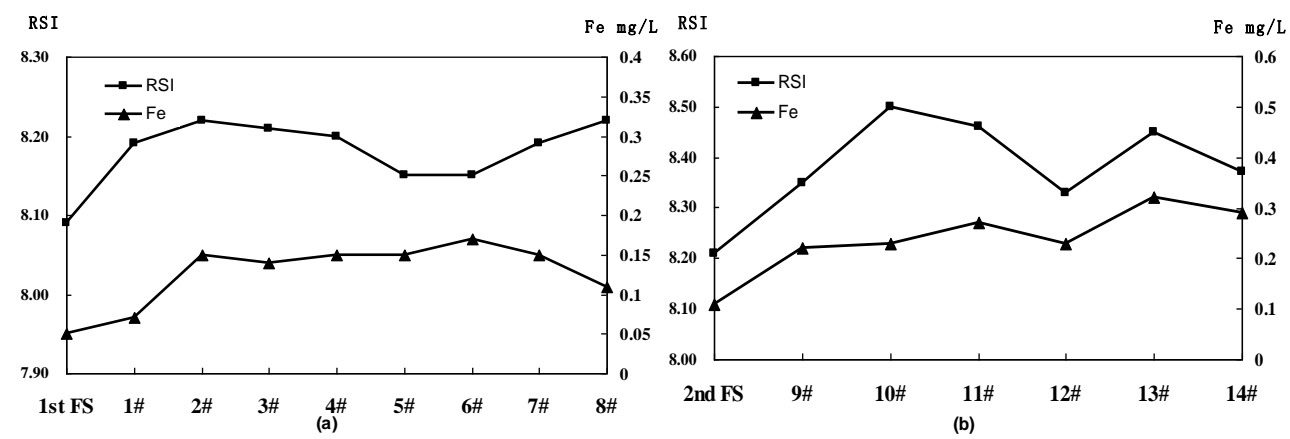

Figure 2. Variation of iron content and RSI in the first (a) and second (b) distribution network

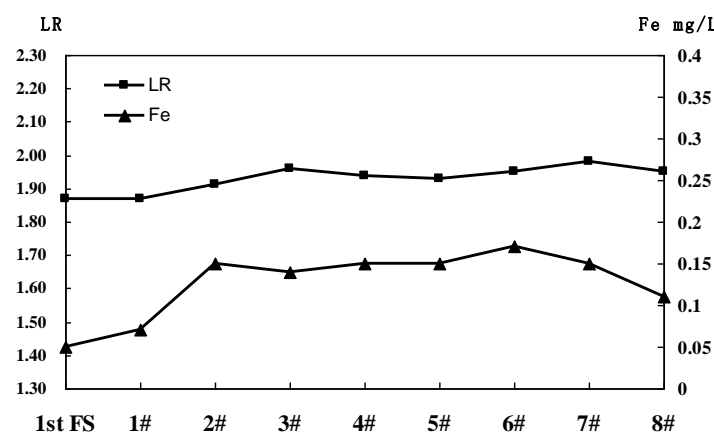

(a)

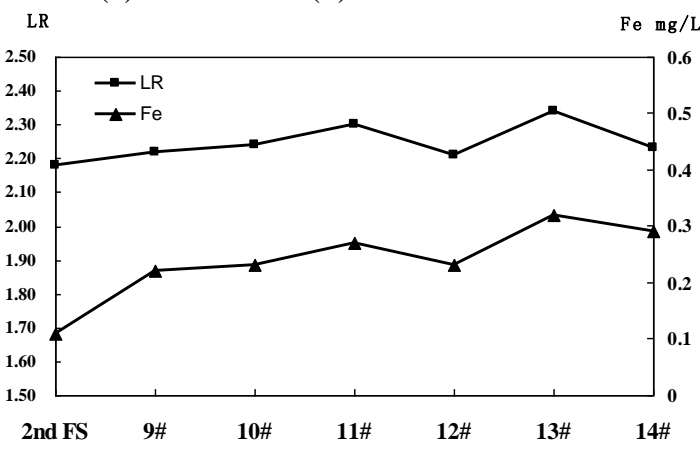

(b)

Figure 3. Variation of iron content and LR in the first (a) and second (b) distribution network

As shown in figure 2 and figure 3, the strong positive correlation between RSI, LR and iron content reveals that these chemical stability indexes can indicate the water corrosion quite well. RSI combines the effects of $\mathrm{pH}$, alkalinity, hardness and dissolved solids. Lower water $\mathrm{pH}$ and alkalinity stimulate the iron corrosion, which also form a higher RSI. LR depends on chlorides, sulfate and alkalinity. The higher LR, the higher chlorides and sulfate content in the pipe water, which benefit the pitting corrosion.

As shown in table 3 and figure 4, positive correlation between DOC and iron content was found in this study, inferring that NOM may stimulate the iron corrosion. It seems that some types of NOM are strongly adsorbed on corrosion scale probably via the interaction of acidic functional groups (e.g. carboxyl) with hydroxylated oxide surface sites[31, 10]. Carboxylic acids are the components of DOC and are also considered as a source of organic carbon (AOC) easily assimilated by heterotrophic bacteria[32]. Wide availability of carboxylic acids confirms again favorable conditions for the microbial existence within the corrosion scale[33]. Thus this would be beneficial for microbial induced corrosion. The changes of NOM structures in static water provide evidence to the bacteria metabolism in the corrosion scales[22].

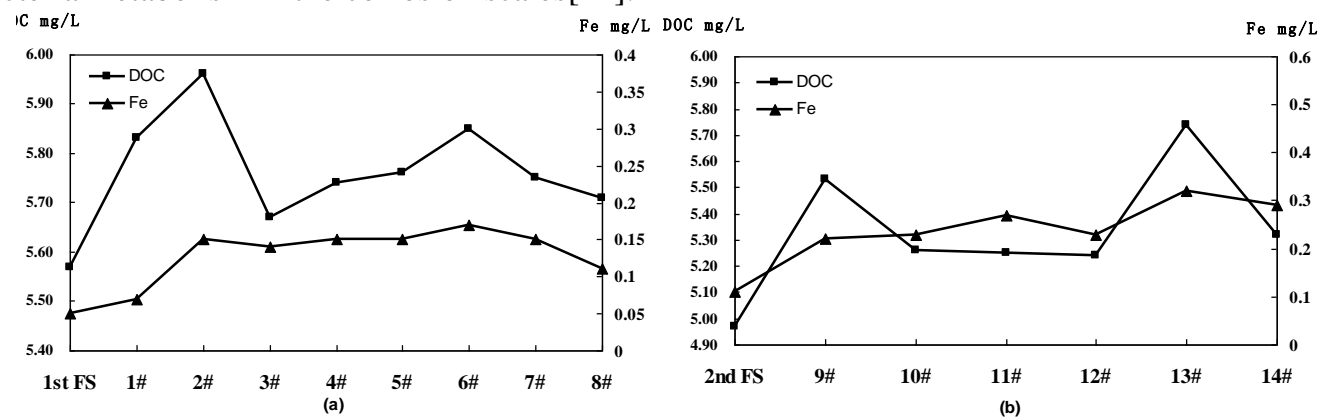

Figure 4 Variation of Iron content and DOC in the first (a) and second (b) distribution network

\section{Conclusions}


Water quality changes in two different water distribution systems supplied by two different water treatment process were investigated and the correlations between different water quality parameters and iron corrosion were analyzed. Compared with the effluent water, in the distribution pipelines, water $\mathrm{pH}$, alkalinity, chlorine residue and sulfate decreased and turbidity, chloride and DOC increased, indicating a growing corrosiveness and aggressiveness of the pipe water. As a result, there exists common iron corrosion in the distribution pipelines. The corrosion scales release cause an increase of iron content and turbidity in pipe water. The chemical stability indexes can indicate the water corrosiveness quite well because of their strong correlation with iron content. Lower $\mathrm{pH}$ and alkalinity were found to stimulate the corrosion rate. Higher chlorides and sulfate may be adsorbed and permeate through the passive layer, causing pitting corrosion. High DOC content would be beneficial for microbial induced corrosion.

\section{Acknowledgments}

This research was supported by the key Special Program of the Science and Technology for the Pollution Control and Treatment of Water Bodies (2017ZX07207-004, 2017ZX07207-005).

\section{References}

[1] Edwards, M. Controlling corrosion in drinking water distribution systems: a grand challenge for the 21 st century. Water Sci. Technol., 2004: 49 (2), 1-8.

[2] McNeill, L.S., Edwards, M. Iron pipe corrosion in distribution systems. J. AWWA, 2001:88 (7), 88-100.

[3] Franzmann, P.D., Heitz, A., Zappia, L.R., Wajon, J.E., Xanthis, K. The formation of malodorous oligosulphides in treated groundwater. The role of biofilms and potential precursors. Water Res., 2001:35 (7), $1730-1738$.

[4] Cheng, X., Peterkin, E., Burlingame, G.A. A study on volatile sulfide causes of odors at Philadelphia's northeast water pollution control plant. Water Res., 2005:39, 3781-3790.

[5] Sander, A., Berghult, B., Broo, A.E., Johansson, E.L., Hedberg, T. Iron corrosion in drinking water distribution systems - surface complexation aspects. Corrosion Sci., 1997:39 (1), 77-93.

[6] Chandy, J.P., Angles, M.L. Determination of nutrients limiting biofilm formation and the subsequent impact on disinfectant decay. Water Res., 2001:35 (11), 2677-2682.

[7] Huck, P.M., Gagnon, G.A. Understanding the distribution systemas a bioreactor: a framework for managing heterotrophic plate count levels. Int. J. Food Microbiol., 2004:92,347-353.

[8] Kuch, A. Investigations of the reduction and re-oxidation kinetics of iron(III) oxide scales formed in waters. Corrosion Sci., 1988:28 (3), 221.

[9] Benjamin, M.M., Sontheimer, H., Leroy, P. American Water Works Association Research Foundation \& DVGW Technologiezentrum Wasser. Internal Corrosion of Water Distribution Systems, second ed. American Water Works Association, Denver, CO., 1996.

[10] Camper, A.K. Involvement of humic substances in regrowth. Int. J. Food Microbiol., 2004:92, $355-364$.

[11] Imran, S.A., Dietz, J.D., Asce, M.,Mutoti, G., Taylor, J.S., Randall, A.A. Modified Larsons ratio incorporating temperature, water age, and electroneutrality effects on redwater release. J.Environ. Eng., 2005a: $11,1514-1520$.

[12] LeChevallier, M.W., Lowry, C.D., Lee, R.G., Gibbon, D.L. Examining the relationship between iron corrosion and the disinfection of biofilm bacteria. J. AWWA, 1993:85 (7), 11-23.

[13] Langelier W.F. The Analytical Control of Anti-Corrosion Water Treatment. J. AWWA, 1936: 28(10), 1500-1505

[14] Ryznar J.W. A new Index for Determining Amount of Calcium Carbonate Scale Formed by a Water. J. AWWA, 1944:36(4): 472-477

[15] Larson, L.E., Scold, R.V. Laboratory studies relation mineral quality of water to corrosion of steel and cast iron. Corrosion, 1958:14, 285-293.

[16] AWWARF, DVGW2TZW. Internal Corrosion of Water Distribution Systems. Denver: AWWARF, 1996.

[17] Génin, J.-M.R., Ruby, Ch. Composition and anion ordering in some FeII-III hydroxysalt green rusts (carbonate, oxalate, methanoate): the fougerite mineral. Solid State Sci., 2008:10, 244-259.

[18] Refait, Ph, Memet, J.-B., Bon, C., Sabot, R., Genin, J.-M.R. Formation of the Fe(II)-Fe(III) hydroxysulphate green rust during marine corrosion of steel. Corrosion Sci., 2003:45, 833-845.

[19] Tuovinen, O.H., Button, K.S., Vuorinen, A., Carlson, L., Mair, D.M., Yut, L.A. Bacterial, chemical, and mineralogical characteristics of tubercles in distribution pipelines. J. AWWA, 1980:72 (11), 626-635.

[20] Morton, S.C., Zhang, Y., Edwards, M.A. Implications of nutrient release from iron metal for microbial 
regrowth in water distribution systems. Water Res., 2005:39, 2883-2892.

[21] Beech, I.B., Gaylarde, C.C. Recent advances in the study of biocorrosion - an overview. Rev. Microbiol., 1999:30, 177-190.

[22] Nawrocki. J, Urszula Raczyk-Stanis1awiak, Joanna S’ wietlik, Anna Olejnik, Miroslawa J. Sroka. Corrosion in a distribution system: steady water and its composition. Water Res., 2010:.

[23] Refait, Ph., Abdelmoula, M., Genin, M.J. Synthesis and characterization of the Fe(II-III) hydroxyl-formate green rust. Hyperfine Interact., 2006a:167, 717-722.

[24] Refeit, Ph., Abdelmoula, M., Genin, J.-M.R., Sabot, R. Green rusts in electrochemical and microbially influenced corrosion of steel. C.R. Geosci., 2006b:338, 476-487.

[25] Boffardi, B.P. Minimization of lead corrosion in drinking water, Mater. Performance, 1990:29 (8), 45 - 49.

[26] Lasheena, M.R., Sharaby, C.M., El-Kholy, N.G., Elsherif, I.Y., El-Wakeel, S.T. Factors influencing lead and iron release from some Egyptian drinking water pipes. J. Haz. Mat., 2008:160, 675-680.

[27] Sontheimer, H., Kolle, W. and Snoeyink, V.L. The siderite model of the formation of corrosion-resistant scales. J. AWWA., 1981:73, 572.

[28] Baylis, J.R., 1926. Prevention of corrosion and "red water". JAWWA 15, 598-633.

[29] Strehblow, H.H. Breakdown of passivity and localized corrosion: theoretical concepts and fundamental experimental results. Werkstoffe and Korrosion, 1984:35, 437.

[30] Lin, C. J., Tian, Z.W. The chemical composition characteristics of passive film on 304 stainless steel surface in $\mathrm{Cl}^{-}$containing solution. J Chin Soc Corrosion Protection, 1995:(2), 117-125.

[31] Korshin, G.V., Benjamin, M.M., Sletten, R.S. Adsorption of natural organic matter (NOM) on iron oxide: effects on NOM composition and formation of organo-halide compounds during chlorination. Water Res., 1997:31 (7), 1643-1650.

[32] Bachmann, R.T., Edyvean, R.G.J. Biofouling: an historic and contemporary review of its causes, consequences and control in drinking water distribution systems. Biofilms, 2005:2, 197-227.

[33] Ona-Nguema, G., Abdelmoula, M., Jorand, F., Benali, O., Ge’ hin, A., Block, J.-C., Ge’ nin, J.-M.R. Iron (II, III) hydroxycarbonate green rust formation and stabilization from lepidocrocite bioreduction. Environ. Sci. Technol., 2002:36, 16-20. 